\author{
VITALE DEIANA $^{1}$ - CLAUDIA PINNA ${ }^{1}$ - FRANCO BUFFA ${ }^{1}$ - ROBERTO MANNU RI $^{1,2 *}$ \\ ALBERTO SATTA $^{1}$ - IGNAZIO FLORIS ${ }^{1}$
}

\title{
POPULATION DYNAMICS AND SEASONAL ABUNDANCE OF THAUMASTOCORIS PEREGRINUS IN EUCALYPTUS PLANTATIONS IN SARDINIA (ITALY) $\left.{ }^{1}{ }^{1}\right)$
}

\author{
${ }^{1}$ ) Dipartimento di Agraria, Sezione di Patologia Vegetale ed Entomologia, Università degli Studi di Sassari, Viale Italia \\ 39, 07100, Sassari \\ ( $^{2}$ Istituto per lo Studio degli Ecosistemi, Consiglio Nazionale delle Ricerche, Traversa la Crucca 3, 07100, Sassari \\ *Corresponding author: rmannu@uniss.it
}

Deiana V., Pinna C., Buffa F., Mannu R., Satta A., Floris I. - Population dynamics and seasonal abundance of Thaumastocoris peregrinus in Eucalyptus plantations in Sardinia (Italy)

\begin{abstract}
Thaumastocoris peregrinus is a eucalyptus pest native to Australia. It is currently the only species belonging to the Thaumastocoridae family in Europe. In Italy, it was reported for the first time in Latium in 2011, whereas in Sardinia it was detected in January 2015 on a Eucalyptus camaldulensis plantation located in the south of the island. Our research team carried out a monitoring program for two-years in order to verify its geographical distribution, the main periods of infestation, the flight peaks of the adults and to also detect the presence of unhatched eggs on leaves. During the first year, the occurrence of adults of $T$. peregrinus was verified by yellow sticky traps placed in twelve areas distributed throughout the island where Eucalyptus plantations were located. In the second year, the population dynamics and the occurrence of eggs on leaves were evaluated only in three representative study areas, already included in the previous monitoring program, located in the north, centre and south of the island, respectively. Field surveys showed the presence of $T$. peregrinus in all the monitored locations. The highest adult population was observed from late summer to initial autumn, with a significant increase in adults caught by yellow sticky traps from August, which reached its peak in September and gradually decreased in the following months. The presence of eggs of T. peregrinus on leaves from June to December also indicates that the insect is currently well established in the region.
\end{abstract}

KEY WORDS: bronze bug, Eucalyptus pest, nonnative species, monitoring.

\section{INTRODUCTION}

The bronze bug Thaumastocoris peregrinus Carpintero et Dellapé (Hemiptera Thaumastocoridae) is a sap-feeding insect native to Australia, which infests plant species belonging to Myrtaceae (NOACK et al., 2011). Its common name is due to the symptoms associated with infestation: adults and nymphs feeding on leaves lead to a decrease in the photosynthetic area and leaf discoloration, followed by leaf silvering and tanning (DiAs et al., 2014).

Bronze bug infestations cause tree defoliation, branch dieback, and reduction in tree growth, as well as tree death when attacks are particularly severe and prolonged (JACOBS and Neser, 2005; NAdel et al., 2015). T. peregrinus thus represents a potential key pest of different plant species, especially in areas where the insect has been newly introduced.

The bronze bug has been recently found in several areas outside its native range, such as South Africa (JACOBS and Neser, 2005), Argentina (NoACK and Coviella, 2006), Uruguay (MARTíNEZ and BIANCHI, 2010), Brazil (WILCKEN et al., 2010), Italy (LAUDONIA and SASSO, 2012), Portugal (GARCIA et al., 2013), and Mexico (JiMENEZ-Quiroz et al., 2016). Mediterranean and subtropical areas are considered

\footnotetext{
${ }^{1}$ Original scientific contribution presented and discussed at the National Symposium on "Health status of Eucalyptus plantations in Italy", Oristano (Centro Congressi Hotel Anfora, Tramatza) - Italy, March 24-25, 2017.
}

to be the most suitable for $T$. peregrinus worldwide, as already observed by the analysis of its potential global distribution (MONTEMAYOR et al., 2015; SAAVEDRA et al., 2015). Among all potential hosts, T. peregrinus has been generally associated with several Eucalyptus species (LAUdonia and Sasso, 2012; Soliman et al., 2012; GARCIA et al., 2013), and different development rates and levels of infestation have been observed among the plant species on which it develops (JACOBS and NESER, 2005; NoAcK and Coviella, 2006; IDE et al., 2011; Soliman et al., 2012; BARBOSA et al., 2014; SANTADINO et al., 2017).

SolimAn et al. (2012) showed that the longevity of bronze bug adults varies from 4 to 78 days, and males generally live longer than females. On average, E. urophylla and E. grandis were found to be the most suitable species for the development and reproduction of $T$. peregrinus under laboratory conditions (SOLIMAN et al., 2012). However, T. peregrinus develops well on other Eucalyptus species, such as E. camaldulensis (LAUDONIA and SASSO, 2012; SOlimAn et al., 2012; GARCIA et al., 2013), thus leading to severe infestations and serious damages (JACOBS and NESER, 2005; GARCIA et al., 2013).

E. camaldulensis is the most important Eucalyptus species cultivated in Italy, and is used as a windbreak and as ornamental plants in parks and gardens, as well as being cultivated for biomass fuel. In Italy, Eucalyptus plantations are located above all in central-southern regions, including Sardinia and Sicily (DEIDDA et al., 2016).

In Sardinia, E. camaldulensis was introduced at the beginning of the last century and primarily in land 
reclamation areas. Today, Eucalyptus plantations are predominantly at less than $400 \mathrm{~m}$ above sea level (DEIDDA et al., 2016), covering approximately 23,000 hectares and representing one of the main regions for Eucalyptus plantations in Italy (GASPARINI and TABACCHI, 2011). Eucalyptus trees are commonly found in several agricultural and forest landscapes in Sardinia and their flowers are valuable sources of nectar and pollen (FLORIS et al., 2007). The presence of T. peregrinus in such areas has a negative impact on the phytosanitary status of Eucalyptus, which has already been affected by several phytophagous species such as psyllids, particularly the red gum lerp psyllid Glycaspis brimblecombei Moore (Hemiptera Aphalaridae) (DEIDDA et al., 2016; MANNU et al., 2018).

A monitoring network in Sardinia covering different Eucalyptus distribution areas was carried out to: 1) obtain information on the distribution of $T$. peregrinus in Sardinia; 2) evaluate the seasonal abundance and main periods of infestation of bronze bug under Mediterranean conditions. We had already conducted similar study for $G$. brimblecombei (FLORIS et al., 2018; MANNU et al., 2018).

\section{MATERIALS AND METHODS}

FIELD SURVEYS AND SAMPLING PROCEDURE

Field surveys were carried out in 2015 and 2016, and stations were selected to cover the northern, central and southern parts of Sardinia. In 2015, four stations for each macroarea for a total of 12 were monitored, and three stations (one for each macroarea) were surveyed in 2016 (Fig. I): "Santa Maria La Palma" (Northern), "Ottana" (Central) and "Uta" (Southern). In both years we monitored the "Uta" location as it was the nearest to the first observation site of T. peregrinus in Sardinia (DI LASCIO and NANNINI, 2016).

Adults of T. peregrinus were monitored in 2015 and 2016 using yellow sticky traps, which are considered to be one of the most effective methods for capturing adults (NADEL et al., 2015). Four yellow sticky traps $(20 \times 20$ $\mathrm{cm})$ were placed in four different Eucalyptus trees randomly selected at each location. Traps were positioned on branches located in the middle of the canopy, which is the best position to capture T. peregrinus adults (MARTÍNEZ et al., 2010; NADEL and NOACK, 2012; NADEL et al., 2015).

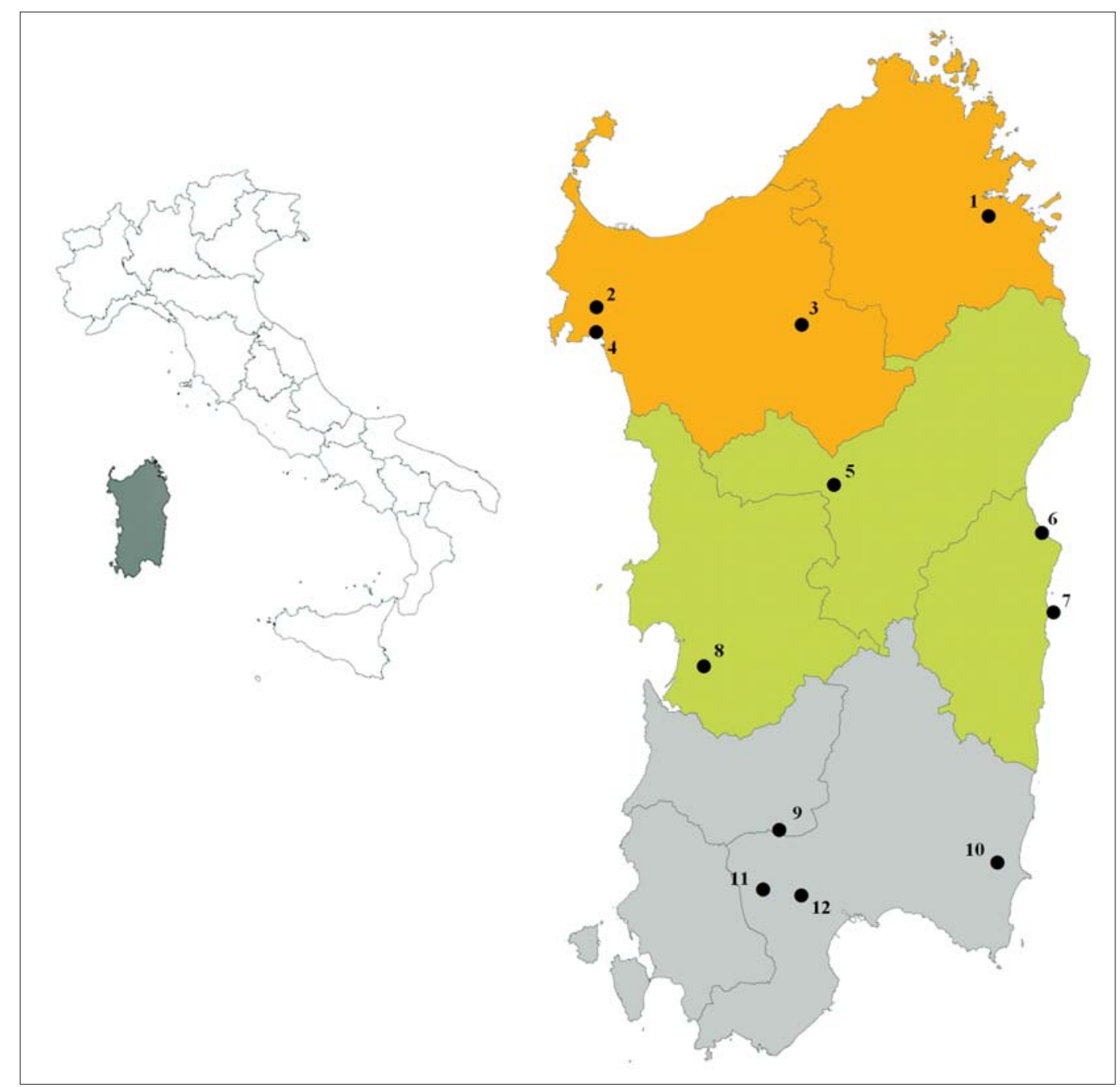

Fig. I - Distribution of locations constituting the monitoring network of T. peregrinus adults and eggs in Sardinia (Italy). Numbers from 1 to 12 indicating each location are sorted according to a North-South gradient (1="Olbia"; $2=$ "Santa Maria La Palma"; 3="Ozieri"; 4="Alghero"; 5="Ottana"; 6="Siniscola"; 7="Arbatax"; 8="Arborea"; 9="Serramanna"; 10="San Vito"; 11="Siliqua"; 12="Uta"). Different colors in the map indicate different geographical areas (Orange=North Sardinia; Green=Central Sardinia; Grey=South Sardinia). 
The traps were collected and replaced biweekly in the summer and monthly in other seasons. The traps collected in the field were then taken to the laboratory where the $T$. peregrinus adults were counted

Observations of eggs were conducted only in 2016. At each location and sampling date, four branchlets of approximately $40 \mathrm{~cm}$ in length were collected from the canopy of the four trees. Again, samplings were carried out from the middle of the canopy, as it is also recommended for assessing the density of bronze bug eggs (MARTíneZ et al., 2010; NADEL et al., 2015; JiMENEZQUIROZ et al., 2016). Each branchlet was collected separately in a plastic bag and transferred to the laboratory, where the numbers of unhatched eggs were counted under a stereoscopic microscope on both sides of four mature leaves per branch.

\section{STATISTICAL ANALYSIS}

All statistical analysis were performed using R software (R CORE TEAm, 2016). Firstly, abundance data were $\log (\mathrm{x}+1)$-transformed to satisfy the normality assumption. In order to explore the effects of location on the abundance of $T$. peregrinus adults and eggs, a Linear Mixed Model (LMM) was considered for each year using the lmer function of the "lme4" package in R (BATES et al., 2015). Location was considered as the fixed factor, whereas sampling dates and traps were the random factors. An LMM was fitted to the 2015 monitoring data to evaluate the effects of the different geographical areas on the abundance of $T$. peregrinus adults, considering the geographical areas as the fixed factor and sampling dates and traps as random factors. Analysis of variance (ANOVA) considering Type II Wald F tests with Kenward-Roger correction of degrees of freedom was used to test the significance of factors, followed by Tukey's post-hoc test at a significance level of $p<0.05$ for mean separation.

Finally, a linear regression model approach was used to evaluate the relationship between the average number of eggs and adults captured either at the same or different sampling times. The average monthly numbers of eggs observed in 2016 in all locations were thus compared to those of adults captured either in the same $(t)$, or previous $(t-1)$, or following $(t+1)$ month, by linear regression models. ANOVA was performed to test the significance of the regression models and Pearson's correlation coefficient was calculated to evaluate the relationship between the variables.

\section{RESULTS}

Adults of T. peregrinus were captured in all monitored locations in 2015, and statistical differences among locations were found $\left(\mathrm{F}_{11,40.257}=20.30 ; \mathrm{p}<0.001\right)$. "Serramanna", "Uta", "Olbia" and "Arbatax" were the most infested locations, which showed an average monthly number of adults greater than 10 individuals per trap (Table 1). However, five locations showed average values lower than one adult per month compared to all the monitored areas. Statistical differences in adult abundance were also found between geographical areas $\left(\mathrm{F}_{2,73.158}=7.37\right.$; $\mathrm{p}<0.001)$. The highest and the lowest average monthly number of adults captured by traps was observed in south $(16.3 \pm 3.1)$ and north $(4.2 \pm 1.7)$ Sardinia, respectively. The seasonal abundance of $T$. peregrinus in 2015 was similar in all the geographical areas (Fig. II). The population dynamics of adults was comparable in the three geographical areas, showing an increase in the average number of adults in August and a peak in population abundance from September to October in southern and central Sardinia. Although population abundance increased simultaneously in all areas, in northern Sardinia, the number of adults decreased immediately after September.

Significant differences between the three areas were also found in 2016 both for adults $\left(\mathrm{F}_{2,9}=14.96 ; \mathrm{p}<0.001\right)$ and eggs $\left(F_{2,9}=14.60 ; p<0.001\right)$. The "Ottana" (i.e. central Sardinia) location showed the highest average monthly

Table 1 - Average monthly number of adults per traps and eggs per branch of T. peregrinus captured at 12 and 3 locations distributed throughout Sardinia (Italy) during 2015 and 2016, respectively. Labels identify each location according to North-South gradient. Values are reported as mean \pm standard error. Different letters in a column indicate significant differences in abundance among locations within same year (Tukey's post hoc test, $\mathrm{p}<0.05$ ).

\begin{tabular}{|c|c|c|c|c|c|}
\hline \multirow{2}{*}{ Label } & \multirow{2}{*}{$\begin{array}{l}\text { Geographical } \\
\text { area }\end{array}$} & \multirow{2}{*}{ Location } & \multirow{2}{*}{$\begin{array}{c}2015 \\
\text { Adults }\end{array}$} & \multicolumn{2}{|c|}{2016} \\
\hline & & & & Adults & Eggs \\
\hline 1 & North Sardinia & Olbia & $12.45 \pm 3.90 \mathrm{~b}$ & - & - \\
\hline 2 & North Sardinia & S. M. La Palma & $0.02 \pm 0.02 \mathrm{a}$ & $8.36 \pm 2.58 \mathrm{ab}$ & $0.58 \pm 0.34 \mathrm{a}$ \\
\hline 3 & North Sardinia & Ozieri & $0.09 \pm 0.09 \mathrm{a}$ & - & - \\
\hline 4 & North Sardinia & Alghero & $0.02 \pm 0.02 \mathrm{a}$ & - & - \\
\hline 5 & Central Sardinia & Ottana & $0.03 \pm 0.02 \mathrm{a}$ & $20.54 \pm 5.03 b$ & $7.05 \pm 1.81 \mathrm{~b}$ \\
\hline 6 & Central Sardinia & Siniscola & $6.38 \pm 1.97 b$ & - & - \\
\hline 7 & Central Sardinia & Arbatax & $11.11 \pm 4.00 \mathrm{~b}$ & - & - \\
\hline 8 & Central Sardinia & Arborea & $0.03 \pm 0.02 \mathrm{a}$ & - & - \\
\hline 9 & South Sardinia & Serramanna & $16.67 \pm 5.51 b$ & - & - \\
\hline 10 & South Sardinia & San Vito & $8.72 \pm 3.08 b$ & - & - \\
\hline 11 & South Sardinia & Siliqua & $7.16 \pm 2.61 \mathrm{~b}$ & - & - \\
\hline 12 & South Sardinia & Uta & $16.48 \pm 4.74 b$ & $4.82 \pm 1.28 \mathrm{a}$ & $0.21 \pm 0.07 \mathrm{a}$ \\
\hline
\end{tabular}




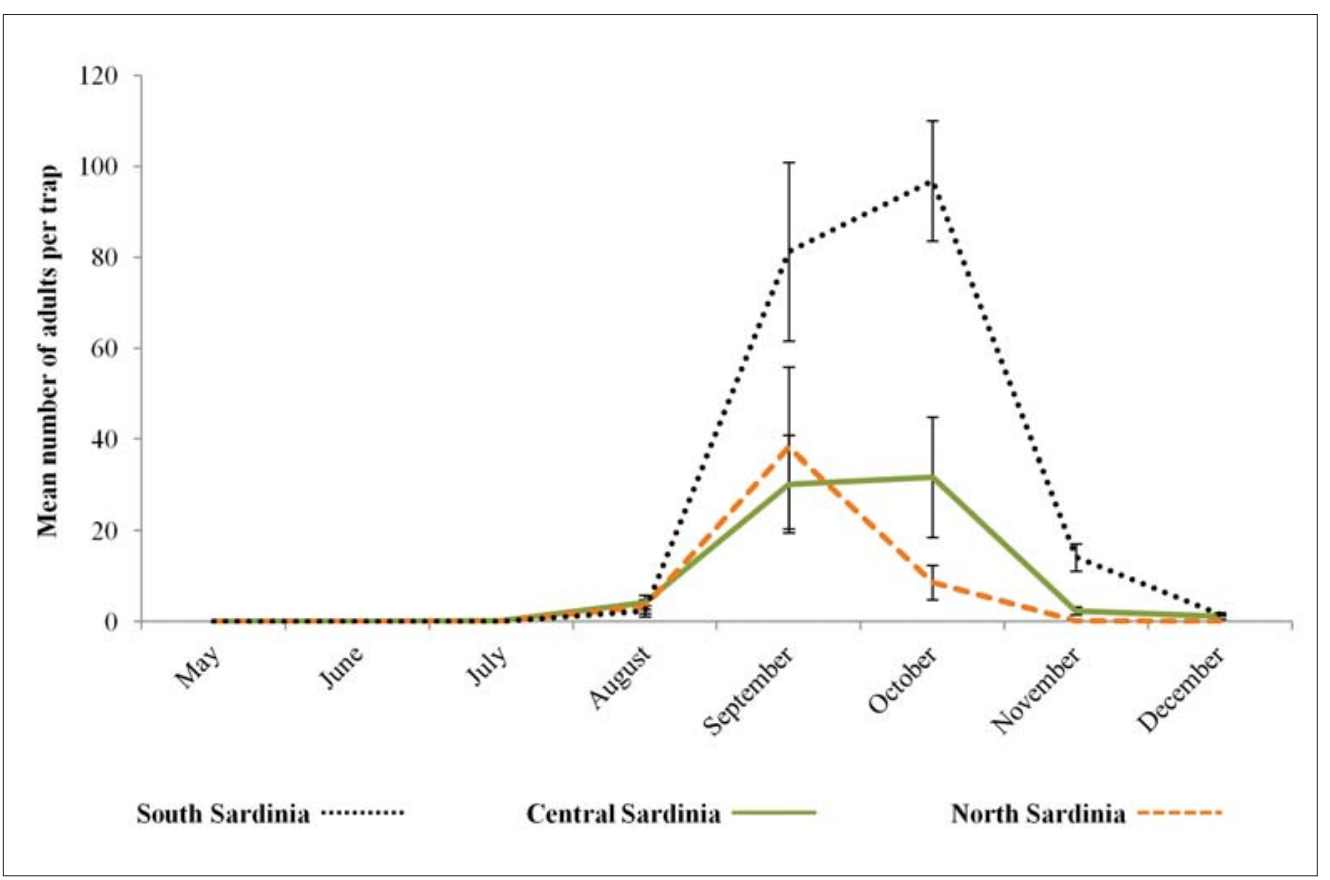

Fig. II - Average number of adults of $T$. peregrinus captured monthly during MayDecember 2015 in South, Central and North Sardinia (Italy). Error bars in graph indicate standard error of the average number of adults per month. values of both adults and eggs compared to the other areas (Table 1). The seasonal abundance of eggs over time was comparable to that of adults in each location (Fig. III). Despite this, adults and egg abundance in "Ottana" reached their peak in August, whereas in other locations an increase in the population of both adults and eggs was observed only after the middle of September. In general, the seasonal abundance of eggs was comparable to that of adults in the same location, with an earlier abundance peak of eggs than of adults.

Finally, the average monthly number of eggs was significantly related to the average number of adults captured in the same month $\left(\mathrm{F}_{1,29}=29.73 ; \mathrm{p}<0.001\right.$; Pearson's $\mathrm{R}=0.72)$ and in the following month $\left(\mathrm{F}_{1,26}=59.49 ; \mathrm{p}<0.001\right.$; Pearson's $\mathrm{R}=0.84$ ). On the other hand, no significant relationship was found between eggs and the average number of adults captured in the previous month $\left(\mathrm{F}_{1,26}=0.62 ; \mathrm{p}=0.43\right.$; Pearson's $\left.\mathrm{R}=0.16\right)$ (Fig. IV).

\section{DISCUSSION}

T. peregrinus is a serious pest of Eucalyptus species worldwide (LAUDONIA and SASSO, 2012; Soliman et al., 2012). The presence of the pest in all monitored locations throughout Sardinia ten months after its first recording confirms that the Mediterranean basin is one of the most suitable areas for its settlement (LAUDONIA and SASSO, 2012; MonTEMAYOR et al., 2015; SAAVEDRA et al., 2015). The rapid diffusion of $T$. peregrinus in Sardinia after its introduction may be due to both its high passive dispersal ability through wind and human transport (WYLIE and SPEIGHT 2012; SASSO et al., 2014), and its capacity to remain active in the field during all seasons (SASSO et al., 2014; NADEL et al., 2015). In Sardinia, the highest population abundance of bronze bug was also observed during the seasonal period characterized by the highest presence of tourists (from August to September). which probably represents one of the most important phoretic means for its spread. However, the insect may also spread during other seasons, as no diapause period has been observed for T. peregrinus (NADEL et al., 2015). The spread of $T$. peregrinus adults in the field on a local scale during all seasons, is also probably positively affected by the emission of different volatile compounds from uninfested trees, which are presumed to act as kairomones on mated females (CAMILA et al., 2013).

The adult population dynamics observed during the first monitoring year in Sardinia was comparable to that reported for other infested regions in Italy (SASSO et al., 2014). In 2015, the adult dynamics followed the same pattern in all three areas in Sardinia, despite the different environmental conditions of the monitored locations (DeIDDA et al., 2016; MANNU et al., 2018). However, a few differences in population dynamics, as well as seasonal abundances, were found from area to area in the second year. Although in southern Sardinia seasonal abundances decreased from the first to the second year, the adult population dynamics did not show a different pattern compared to 2015. In contrast to this, an increase in seasonal abundance was observed both in central and northern Sardinia, likely indicating the spatial expansion of $T$. peregrinus population throughout the Island, in line with the typical pattern of an invasive alien (non native) species (ANDOw et al., 1990). In fact, biological invasions are always characterized by three time-steps (1) introduction of the invasive species, (2) its establishment, and (3) spatial expansion into new areas (ELTON, 1958).

In addition, the adult dynamics recorded in 2016 in central Sardinia was different to those of northern and southern Sardinia observed in the same and previous years. Population dynamics and seasonal abundance are generally affected by different factors, including management and environmental conditions, which both directly and indirectly influence other Eucalyptus pest species (LAUdONIA et al., 2014; MANNU et al., 2018). Of these, water availability, especially during the summer, is considered one of the most influencing factors as it allows a good foliage development which might influence supsucking insect feeding (LAUDONIA et al., 2014).

Finally, the high correlations obtained between the average number of eggs and the average number of adults 


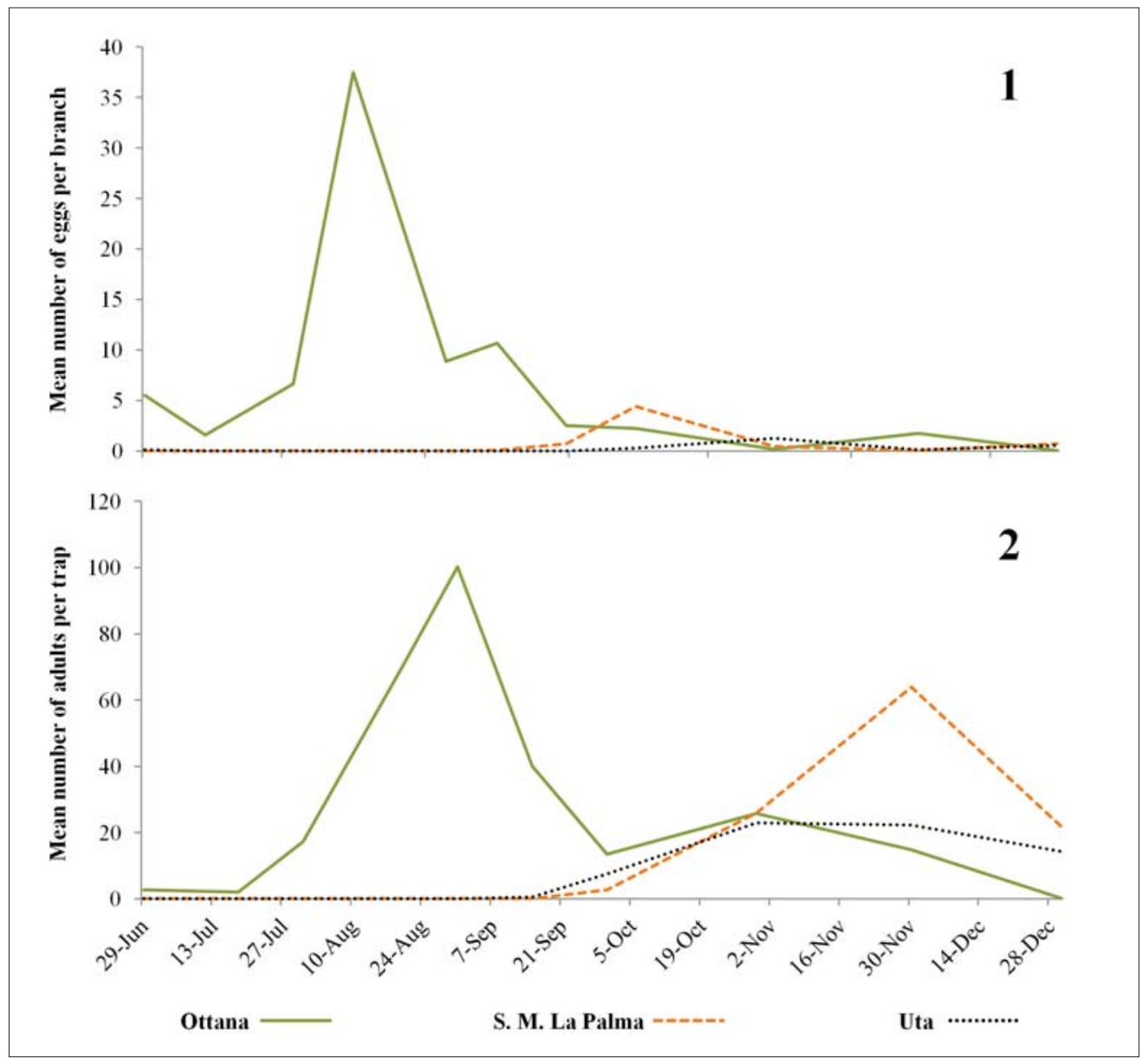

Fig. III - Average number of (1) unhatched eggs per branch and (2) adults per trap of $T$. peregrinus observed at each sampling date during June-December 2016 in Ottana (Central Sardinia), Santa Maria La Palma (Northern Sardinia), and Uta (South Sardinia), respectively.

could be particularly useful for improving monitoring activities. They could enable adult population abundance of the bronze bug to be predicted in the short-term, particularly from the perspective of biological control, e.g. using the specific egg parasitoid Cleruchoides noackae Lin and Huber (Hymenoptera: Mymaridae) (BARBOSA et al., 2017).

\section{CONCLUSIONS}

In Sardinia T. peregrinus is now well established throughout the island just two years after its introduction. The presence of bronze bug complicates the health of Eucalyptus plantations, which are already being affected by the presence of various phytophagous and several phytopathogens (DEIDDA et al., 2016). This highlights the need to take phytosanitary measures to contain and limit the entry of other new species which could lead to irreversible ecological changes and economic losses. In accordance with Italian legislation, we are now evaluating the possibility of introducing the specific egg parasitoid $C$. noackae, due to its promising potential for the biological control of T. peregrinus (BARBOSA et al., 2017).

\section{ACKNOWLEDGMENTS}

The authors gratefully acknowledge the "Regione Autonoma della Sardegna, Tavolo Tecnico Difesa Fitosanitaria Piante Forestali, Assessorato Difesa Ambiente Servizio Tutela del suolo e politiche forestali" for the financial support of the research project "Programma triennale di controllo biologico della Psilla lerp dell'eucalipto Glycaspis brimblecombei e monitoraggio delle problematiche fitosanitarie dell'eucalipto in Sardegna".

\section{REFERENCES}

Andow D.A., Kareiva P.M., Levin S.A., OKubo A., 1990 - Spread of invading organisms. - Landscape Ecology, 4: $177-188$.

Barbosa L.R., Wrege M.S., Caramori P.H., Soranso M., ARAúso M.M., 2014 - Monitoramento e distribuição de ocorrência de Thaumastocoris peregrinus no Estado do Paraná. - Comunicado técnico 337, Colombo,PR, pp. 6.

Barbosa L.R., Peruffo Rodrigues A., Da Silva Soler L., Vique Fernandes B., Monteiro De Castro E Castro B.,Wilcken C.F., Zanuncio J., 2017 Establishment in the Field of Cleruchoides noackae (Hymenoptera: Mymaridae), an Exotic Egg Parasitoid of Thaumastocoris peregrinus (Hemiptera: Thaumastocoridae). - Florida Entomologist, 100(2): 372-374.

Bates D., Maechler M., Bolker B., Walker S., 2015 Fitting Linear Mixed-Effects Models Using lme4. Journal of Statistical Software, 67(1): 1-48.

Camila B., Martins C., Paulo H., Zarbin G. - 2013. Volatile organic compounds of conspecific-damaged Eucalyptus benthamii influence responses of mated females of Thaumastocoris peregrinus. - Journal of Chemical Ecology, 39(5): 602-611. 
Deidda A., Buffa F., Linaldeddu B.T., Pinna C., Scanu B., Deiana V., Satta A., Franceschini A., Floris I., 2016 - Emerging pests and diseases threaten Eucalyptus camaldulensis plantations in Sardinia, Italy. - iForest Biogeosciences and Forestry, 9: 883-891.

Dias T.K.R., Wilcken C.F., Soliman E.P., Barbosa L.R., Serrão J.E., Zanuncio J.C., 2014 - Predation of Thaumastocoris peregrinus (Hemiptera: Thaumastocoridae) by Atopozelus opsimus (Hemiptera: Reduviidae) in Brazil. - Invertebrate Survival Journal, 11: 224-227.

Di LASCIO A., NANNini M., 2016 - A survey of the bronze bug Thaumastocoris peregrinus on Eucalyptus camaldulensis in the site of its first recovery in Sardinia (Italy). - Communications in agricultural and applied biological sciences, 81(3): 307-308.

Elton, C.S. 1958 - The Ecology of Invasions by Animals and Plants. Methuen \& Co LTD, London, UK, $181 \mathrm{pp.}$

Floris I., SATTA A., RuIU L., 2007 - Honeys of Sardinia (Italy). - Journal of Apicultural Research, 46(3):198209.

Floris I., Cocco A., Buffa F., Mannu R., Satta A., 2018 - Insect pests of Eucalyptus plantations in Sardinia (Italy) - Redia, 101: 61-71. http://dx.doi.org/ 10.19263/REDIA-101.18.09

Garcia A., Figueiredo E., Valente C., Monserrat V.J., BRANCO M., 2013 - First record of Thaumastocoris peregrinus in Portugal and of the neotropical predator Hemerobius bolivari in Europe. - Bulletin of Insectology, 66: 251-256.

GASPARINI P., TABACCHI, G., 2011 - L'Inventario Nazionale delle Foreste e dei serbatoi forestali di Carbonio INFC 2005. Secondo inventario forestale nazionale italiano. Metodi e risultati. Ministero Delle Politiche Agricole, Alimentari e Forestali, Corpo Forestale dello Stato. Consiglio per la Ricerca e la Sperimentazione in Agricoltura, Unità di ricerca per il Monitoraggio e la Pianificazione Forestale. Edagricole-Il Sole 24 ore, 653 pp.

Ide M.S., Ruiz C.G., SAndoval A.C., Valenzuela J.E., 2011 - Detection of Thaumastocoris peregrinus (Hemiptera: Thaumastocoridae) associated to Eucalyptus spp. in Chile. - Bosque, 32: 309-313.

JACOBS D.H., NESER S., 2005 - Thaumastocoris australicus Kirkaldy (Heteroptera: Thaumastocoridae): a new insect arrival in South Africa, damaging to Eucalyptus trees. - South African Journal of Science, 101 (5/6): 233-236.

Jimenez-Quiroz E., Vanegas-Rico J.M., MoralesMartínez O., LOMELI-FLORES J.R., RodRÍGUEZ-LEYVA E., 2016 - First Record of the Bronze Bug, Thaumastocoris peregrinus Carpintero and Dellapé 2006 (Hemiptera: Thaumastocoridae), in Mexico. Journal of Agricultural and Urban Entomology 32(1): 35-39.

Laudonia S., Margiotta M., SAsso R., 2014 - Seasonal occurrence and adaptation of the exotic Glycaspis brimblecombei Moore (Hemiptera: Aphalaridae) in Italy. - Journal of Natatural History, 48: 675-689.

LAUdonia S., SAsso R., 2012 - The bronze bug Thaumastocoris peregrinus: a new insect recorded in Italy, damaging to Eucalyptus trees. - Bulletin of Insectology, 65(1): 89-93.

Mannu R., Buffa F., Pinna C., Deiana V., Satta A., FLORIS I. - 2018. Preliminary results on the spatiotemporal variability of Glycaspis brimblecombei
(Hemiptera Psyllidae) populations over three-year monitoring in Sardinia (Italy). - Redia, 101: 107-114. http://dx.doi.org/10.19263/REDIA-101.18.14

MARTínez G., BIANCHI M., 2010 - First record in Uruguay of the bronze bug, Thaumastocoris peregrinus Carpintero and Dellapé, 2006 (Heteroptera: Thaumastocoridae). - Agrociencia, 14(1): 15-18.

Martínez G., GonzÁlez A., Simeto S., Balmelli G., 2010 - Monitoring the bronze bug, Thaumastocoris peregrinus (Heteroptera: Thaumastocoridae): effect of trap placement. In: Proceeding of the "XXIII IUFRO World Conference". Seoul, Korea.

Montemayor S.I., Dellape P.M., Melo M.C., 2015 Geographical distribution modelling of the bronze bug: $A$ worldwide invasion. - Agricultural and Forest Entomology, 17(2): 129-137.

NAdel R.L., NOACK A.E., 2012 - Current understanding of Thaumastocoris peregrinus in the quest for its management and control. - International Journal of Pest Management, 58(3): 257-266.

Nadel R.L., Wingfield M.J., Scholes M.C., Garnas J.R., Lawson S.A., Slippers B., 2015 - Population dynamics of Thaumastocoris peregrinus in Eucalyptus plantations of South Africa. - Journal of Pest Science, 88(1): 97-106.

NoACK A.E., Coviella C.E., 2006 - Thaumastocoris australicus Kirkaldy (Hemiptera: Thaumastocoridae): First record of this invasive pest of eucalyptus in the Americas. - General and Applied Entomology, 35: 13-14.

NoAcK A.E., CAssis G., Rose H.A., 2011 - Systematic revision of Thaumastocoris Kirkaldy (Hemiptera: Heteroptera: Thaumastocoridae). - Zootaxa, 3121: 160.

R CoRe TeAm, 2016 - R: A Language and Environment for Statistical Computing. R Foundation for Statistical Computing, Vienna, Austria. https://R-project.org/.

SaAvedra M.C., Avila G.A., Withers T.M., Holwell G.I., 2015 - The potential global distribution of the Bronze bug Thaumastocoris peregrinus Carpintero and Dellapé (Hemiptera: Thaumastocoridae). - Agricultural and Forest Entomology, 17(4): 375-388.

Santadino M., Lucia A., Duhour A., Riquelme M., Naspi C., Masuh H., Liljesthröm G., Coviella C., 2017 - Feeding preference of Thaumastocoris peregrinus on several Eucalyptus species and the relationship with the profile of terpenes in their essential oils. - Phytoparasitica, 45(3): 395-406.

Sasso R., Mughini G., Laudonia S., 2014 - Primi dati su fenologia e distribuzione in Italia di Thaumastocoris peregrinus Carpintero and Dellapé (Heteroptera: Thaumastocoridae), la cimicetta della bronzatura dell'eucalipto. - Forest@11: 105-115.

Soliman E.P., Wilcken C.F., Pereira J.M., Dias T.K.R., Zache B., Dal Pogetto M.H.F.A., Barbosa L.R., 2012 - Biology of Thaumastocoris peregrinus in different eucalyptus species and hybrids. - Phytoparasitica, 40(3): 223-230.

Wilcken C., Soliman E., De Sá L., Barbosa L.R., Dias T.K.R., Ferreira-Filho P., Rodrigues Oliveira R., 2010 - Bronze bug Thaumastocoris peregrinus Carpintero and Dellapé (Hemiptera: Thaumastocoridae) on Eucalyptus in Brazil and its distribution. - Journal of Plant Protection Research, 50(2): 201-205.

WyLIE F.R., SPEIGHT, M.R., 2012 - Insect pests in tropical forestry (2nd edition). CABI, Wallingford, UK, 365 pp. 